\title{
Development of insulin and proinsulin secretion in newborn pony foals
}

\author{
N B Holdstock, V L Allen, M R Bloomfield ${ }^{1}$, C N Hales ${ }^{2}$ and \\ A L Fowden ${ }^{1}$ \\ Department of Clinical Veterinary Medicine, University of Cambridge, Cambridge CB3 OES, UK \\ ${ }^{1}$ Department of Physiology, University of Cambridge, Cambridge CB2 3EG, UK \\ ${ }^{2}$ Department of Clinical Biochemistry, University of Cambridge, Cambridge CB2 2QR, UK \\ (Requests for offprints should be addressed to NB Holdstock, Department of Clinical Veterinary Medicine, University of Cambridge, Madingley Road, \\ Cambridge CB3 OES, UK; Email: nbh10@cam.ac.uk)
}

\begin{abstract}
At birth, the endocrine pancreas must assume a glucoregulatory role if the neonate is to survive the transition from parenteral to enteral nutrition. In species like the horse, neonatal hypoglycaemia is common, which suggests that the glucoregulatory mechanisms are not always fully competent at birth. Hence, this study examined pancreatic $\beta$ cell function in newborn foals during nutritional adaptation over the first 10 days post partum. Over a $48 \mathrm{~h}$ period at three time intervals after birth (days 1-2, 5-6 and 9-10 post partum), the $\beta$ cell responses to suckling and to intravenous administration of glucose, arginine and saline were measured in seven normal pony foals. Basal plasma concentrations of proinsulin, but not insulin or glucose, increased significantly between days 1 and 10 . Suckling caused a gradual increase in plasma glucose, which was accompanied by a significant increase in plasma insulin concentrations $15 \mathrm{~min}$ after the onset of suckling on days 5 and 9 , but not day 1 . There was no significant change in plasma proinsulin concentrations in response to suckling at
\end{abstract}

any age. At all ages studied, glucose and arginine administration stimulated an increase in the plasma concentrations of insulin and proinsulin; these $\beta$ cell responses did not change significantly with postnatal age. The insulin responses to glucose were significantly greater than those of arginine at each time period. Glucose clearance was significantly slower on day 1 than subsequently. Proinsulin and glucose, but not insulin, concentrations decreased significantly after saline administration at all three ages. At each time period, there was a significant positive relationship between the plasma insulin and proinsulin concentrations, the slope of which was significantly shallower on days 1-2 than subsequently. These results show that equine $\beta$ cells are responsive to glucose and arginine and release both insulin and proinsulin during the immediate postnatal period. They also suggest that newborn foals may be insulin resistant on the first day after birth.

Journal of Endocrinology (2004) 181, 469-476

\section{Introduction}

At birth, the continuous placental supply of nutrients ceases and is replaced by an intermittent supply of substrates via the gut (Trahair \& Sangild 1997, Fowden et al. 1998). During this switch from parenteral to enteral nutrition, maintenance of normoglycaemia depends, in part, on the glucoregulatory endocrine glands (Fowden et al. 2001). Prenatally, fetal glucose concentrations are controlled primarily by maternal glucose availability and, hence, endocrine glands such as the pancreas are less directly involved in glucose homeostasis before than after birth. However, the endocrine pancreas must be able to assume a glucoregulatory role shortly after birth, if the neonate is to survive the transition to enteral feeding (Trahair \& Sangild 1997, Fowden et al. 2001). In some species, such as the horse, episodes of hypoglycaemia are common during the neonatal period (Spurlock \& Furr 1990, Madigan 1991), which suggests that the glucoregulatory mechanisms are not always fully competent at birth.

The endocrine pancreas is functional and responsive before birth in all species studied to date, including the horse (Fowden et al. 1980, Fowden 1985). It secretes insulin in response to glucose and amino acids and has a central role in regulating fetal nutrient utilization and growth (Fowden 1995). Insulin is derived from the larger precursor molecule, proinsulin, by cleavage within the secretory granules of the fetal $\beta$ cells (Orsi et al. 1971) and is released in response to membrane depolarization induced either directly or indirectly via generation of ATP (Fowden \& Hill 2001). Compared with adult plasma, fetal plasma has been found to contain little proinsulin during late gestation, although both intact and split proinsulin are 
present in cord plasma from human infants at birth (Godfrey et al. 1996). In sheep, the pancreatic $\beta$ cells become progressively more responsive towards term and are very sensitive to changes in glycaemia in the immediate neonatal period (Phillips et al. 1981, Aldoretta et al. 1998). Similarly, in horses, there are increases in pancreatic $\beta$ cell sensitivity to glucose during late gestation and, again, between birth and 7 days of postnatal age (Fowden et al. 1980, 1982). However, little is known about the changes in neonatal $\beta$ cell function and proinsulin secretion as the glucoregulatory demands for insulin increase during the establishment of enteral feeding. The aim of this study was, therefore, to examine the insulin and proinsulin responses of newborn foals to endogenous and exogenous stimuli during the critical period of glucoregulatory adaptation in the first 10 days after birth.

\section{Material and Methods}

\section{Animals}

Seven pony foals were used in the study. They were born spontaneously at full term (gestational age range 326-345 days) and classified as normal, mature foals using clinical criteria (Rossdale et al. 1984). Their mean ( \pm S.E.) birth weight was $20 \cdot 3 \pm 1 \cdot 1 \mathrm{~kg}$, and all gained $1-2 \mathrm{~kg}$ per day throughout the 10-day experimental period. The mares delivered unassisted and had normal placentae. The foals were housed with their mothers in individual boxes throughout the experimental period. They sucked ad libitum except during the tests of pancreatic $\beta$ cell function, when they were muzzled for periods of up to $90 \mathrm{~min}$. All procedures were carried out under the Animals (Scientific Procedures) Act 1986.

\section{Experimental procedures}

Between 6 and $8 \mathrm{~h}$ after birth, a long-term polyurethane catheter (Milacath, Mila International Inc., Kentucky, USA) was inserted into a jugular vein of each foal, with the animal under mepivacaine hydrochloride local anaesthesia (Intra-Epicaine, Arnolds Veterinary Products, Shrewsbury, UK). The catheters were placed at least $1 \mathrm{~h}$ before any tests began on day 1 and left in situ for the 10 days of the protocol. The pancreatic $\beta$ cell responses to the endogenous stimulus of suckling and to the exogenous stimulus of intravenous administration of glucose or arginine were measured over $48 \mathrm{~h}$ at three time periods after birth (period 1: days 1 and 2; period 2: days 5 and 6; period 3: days 9 and 10 post partum).

Endogenous stimulation On days 1, 5 and 9, the foals were muzzled for $30 \mathrm{~min}$. At the end of that period, a blood sample $(5-6 \mathrm{ml})$ was taken $(0 \mathrm{~min})$ and the muzzle was removed to allow the foal to suckle from its mother. Further blood samples were taken at 5 and $15 \mathrm{~min}$ after the muzzle had been removed. All foals suckled immediately the muzzle was removed and for at least $2 \mathrm{~min}$.

Exogenous stimulation Foals were allowed to suckle, and were then muzzled throughout the experimental procedure. After $30 \mathrm{~min}$, either glucose $(0.5 \mathrm{~g} / \mathrm{kg}, 40 \%$ glucose, Arnolds Veterinary Products; days 1, 5 and 9) or arginine $(100 \mathrm{mg} / \mathrm{kg}$, L-arginine hydrochloride, SigmaAldrich Co. Ltd, in $20 \mathrm{ml} \mathrm{0.9 \%} \mathrm{w/v} \mathrm{NaCl}$; days 2, 6 and 10) was given intravenously to the foal. Saline $(20 \mathrm{ml} 0 \cdot 9 \%$ $\mathrm{w} / \mathrm{v} \mathrm{NaCl}$ ) was given as a control on days 2,6 and 10 . Blood samples $(5-6 \mathrm{ml})$ were taken immediately before $(0 \mathrm{~min})$ and at 5, 15, 30 and $60 \mathrm{~min}$ after administration of the solutions. The muzzle was then removed and the foals were allowed to suckle ad libitum.

All blood samples were collected into both heparinized tubes $(2.5 \mathrm{ml}$; insulin, proinsulin) and EDTA-containing tubes $(2.5 \mathrm{ml}$; cortisol, glucose, $\alpha$-aminonitrogen). In addition, $1 \mathrm{ml}$ aliquots of samples collected at $0 \mathrm{~min}$ (all experiments) and 5 min (suckling experiment) were added to heparinized tubes containing EGTA and glutathione for the determination of plasma catecholamine concentrations (Silver et al. 1984). All the blood samples were centrifuged at $4{ }^{\circ} \mathrm{C}$ immediately after collection and the plasma was stored at $-20^{\circ} \mathrm{C}$ (insulin, proinsulin, cortisol, glucose, $\alpha$-aminonitrogen) or $-70^{\circ} \mathrm{C}$ (catecholamines) until required for analysis.

\section{Biochemical analyses}

Metabolite concentrations Plasma glucose and $\alpha$-aminonitrogen concentrations were determined colorimetrically as described previously (Prenton \& London 1967, Fowden et al. 1982).

Hormone concentrations Plasma insulin and proinsulin concentrations were assayed on a 1235 AutoDELFIA automatic immunoassay system using a two-step timeresolved fluorimetric assay. The principles of DELFIA (Dissociation Enhanced Lanthanide Fluoroimmunoassay) have been described previously (Hemmilä et al. 1984). All reagents, standards and consumables were those recommended and supplied by the manufacturer (Wallac Oy, Turku, Finland). Insulin concentrations were assayed using AutoDELFIA insulin kits (Kit no. B080-101, Wallac Oy) as descibed by Andersen and co-workers (1993). Interassay coefficients of variation were $3 \cdot 1 \%$ at $29 \cdot 0 \mathrm{pmol} / 1,2 \cdot 1 \%$ at $79 \cdot 4 \mathrm{pmol} / 1,1 \cdot 9 \%$ at $277 \mathrm{pmol} / 1$ and $2 \cdot 0 \%$ at $705 \mathrm{pmol} / \mathrm{l}$. The limit of detection of the insulin assay was $1.3 \mathrm{pmol} / 1$ and the assay was linear to approximately $1100 \mathrm{pmol} / 1$. Cross-reactivities were: intact proinsulin $<0.5 \%$ at $2736 \mathrm{pmol} / 1,32-33$ split proinsulin $1 \%$ at $2800 \mathrm{pmol} / 1$ and C-peptide $<0 \cdot 1 \%$ at $5280 \mathrm{pmol} / 1$. Total proinsulin concentrations were determined using 
Table 1 Mean $( \pm$ S.E.) basal concentrations of metabolites and hormones in seven newborn pony foals with respect to postnatal age

\begin{tabular}{|c|c|c|c|c|c|c|}
\hline & Day 1 & Day 2 & Day 5 & Day 6 & Day 9 & Day 10 \\
\hline Glucose $(\mathrm{mmol} / \mathrm{l})$ & $8 \cdot 12 \pm 0 \cdot 45$ & $10.53 \pm 0.74$ & $8.86 \pm 0.51$ & $9.97 \pm 0.68$ & $8.74 \pm 0.63$ & $10 \cdot 05 \pm 0 \cdot 82$ \\
\hline$\alpha$-Aminonitrogen $(\mathrm{mmol} / \mathrm{l})$ & $2 \cdot 23^{a} \pm 0 \cdot 13$ & $3 \cdot 78^{b} \pm 0 \cdot 33$ & $3 \cdot 56^{b} \pm 0 \cdot 22$ & $3 \cdot 71^{\mathrm{b}} \pm 0 \cdot 34$ & $3 \cdot 11^{\mathrm{b}} \pm 0 \cdot 224$ & $3 \cdot 45^{b} \pm 0 \cdot 36$ \\
\hline Adrenaline (pg/ml) & $29 \cdot 7 \pm 9 \cdot 9$ & $39 \cdot 3 \pm 12 \cdot 3$ & $73 \cdot 1 \pm 19 \cdot 3$ & $59 \cdot 9 \pm 16 \cdot 3$ & $50 \cdot 3 \pm 9 \cdot 7$ & $37 \cdot 9 \pm 10 \cdot 2$ \\
\hline Noradrenaline (pg/ml) & $223 \cdot 8^{a} \pm 21 \cdot 9$ & $209 \cdot 0^{\mathrm{ab}} \pm 18 \cdot 1$ & $180 \cdot 2^{\mathrm{ab}} \pm 39 \cdot 7$ & $182 \cdot 0^{\mathrm{ab}} \pm 21 \cdot 0$ & $162 \cdot 4^{\mathrm{ab}} \pm 22 \cdot 0$ & $148 \cdot 6^{b} \pm 18 \cdot 5$ \\
\hline Insulin $(\mathrm{pmol} / \mathrm{l})$ & $91 \cdot 9 \pm 29 \cdot 2$ & $147 \cdot 1 \pm 30 \cdot 5$ & $139 \cdot 1 \pm 38 \cdot 4$ & $160 \cdot 3 \pm 31 \cdot 7$ & $111 \cdot 5 \pm 31 \cdot 43$ & $156 \cdot 3 \pm 39 \cdot 5$ \\
\hline Proinsulin (pmol/l) & $7 \cdot 0^{\mathrm{a}} \pm 1 \cdot 1$ & $11 \cdot 5^{\mathrm{ab}} \pm 2 \cdot 7$ & $14 \cdot 9^{b c} \pm 3 \cdot 3$ & $16 \cdot 6^{c} \pm 3 \cdot 3$ & $16 \cdot 2^{c} \pm 3 \cdot 1$ & $17 \cdot 2^{\mathrm{c}} \pm 3 \cdot 2$ \\
\hline
\end{tabular}

Values within rows with different superscript letters are significantly different from each other (one-way ANOVA with repeated measures, $P<0 \cdot 05$ ).

an in-house AutoDELFIA method developed at the Department of Clinical Biochemistry, Addenbrookes NHS Trust, Cambridge, UK. The solid-phase capture antibody (3B1), bound to a microtitre plate, was specific for the proinsulin B-chain (Sobey et al. 1989). The detection antibody, specific for the proinsulin C-chain (CPT-3F11) was kindly donated by DakoCytomation Ltd, Angel Drove, Ely, UK. This antibody was subsequently labelled with Europium using the DELFIA Europium labelling kit (no. 1244-302, Wallac Oy). The assay was calibrated with chromatography-purified 32-33 split proinsulin standard, kindly donated by Lilly Research Laboratories (Indianapolis, Indiana, USA). The total proinsulin assay showed $100 \%$ cross-reactivity with human intact proinsulin and 32-33 split proinsulin and $<1 \%$ cross-reactivity with human insulin at $2500 \mathrm{pmol} / 1$. This assay, therefore, measured the total concentration of both intact and split proinsulin. Coefficients of variation were $7 \cdot 6 \%$ at $6.3 \mathrm{pmol} / 1,6 \cdot 5 \%$ at $14 \cdot 0 \mathrm{pmol} / 1$ and $3.9 \%$ at $79.9 \mathrm{pmol} / 1$. The limit of detection of the proinsulin assay was less than $1.25 \mathrm{pmol} / 1$. The assay range, without dilution, was approximately $400 \mathrm{pmol} / 1$. Samples with analyte concentrations greater than the dynamic range of the assays were reanalysed after dilution in a protein-based buffer (DELFIA II Wallac Oy). The insulin and proinsulin concentrations in equine plasma stripped of hormones by charcoal treatment were below the limit of detection for both assays. Dilution of equine plasma with high insulin and proinsulin concentrations using stripped equine plasma produced curves parallel to the standard curves in each assay.

Plasma adrenaline and noradrenaline concentrations were measured by HPLC as described previously (Silver et al. 1987). Briefly, plasma samples were prepared by absorption of 300-500 $\mu \mathrm{l}$ onto acid-washed alumina and $20 \mu \mathrm{l}$ samples of the $100 \mu \mathrm{l}$ perchloric acid eluate were injected onto the column. Before absorption, dihydroxybenzylamine was added to each plasma sample as internal standard. Standard solutions of adrenaline and noradrenaline were also treated in the same way. The limits of sensitivity were $0.07 \mathrm{ng} / \mathrm{ml}$ for adrenaline and $0.05 \mathrm{ng} / \mathrm{ml}$ for noradrenaline. The intra- and inter-assay coefficients of variation were $5 \cdot 8 \%$ and $7 \cdot 3 \%$ for adrenaline and $5 \cdot 0 \%$ and $6 \cdot 2 \%$ for noradrenaline respectively.

\section{Statistical analyses}

Means ( \pm S.E.) are given throughout. Statistical analyses were performed using SigmaStat Statistical Software version 2.0. Statistical significance was assessed using parametric tests, including one- and two-way ANOVA with repeated measures and Student's $t$-test as appropriate. For each experiment, the area under the curve (AUC) for the insulin, proinsulin, glucose and $\alpha$-aminonitrogen responses were calculated as the integrated plasma concentrations after administration of glucose or arginine, from 5 to $60 \mathrm{~min}$ above the baseline concentration at $0 \mathrm{~min}$ for all positive values. The relationships between the plasma concentrations of insulin and proinsulin were assessed using linear regression analysis. For all statistical tests, significance was accepted at $P<0 \cdot 05$.

\section{Results}

\section{Basal metabolite and hormone concentrations}

The samples collected at 0 min after the foals had been muzzled for $30 \mathrm{~min}$ on days 1, 2, 5, 6, 9 and 10 were used to assess changes in the basal metabolite and hormone concentrations over the first 10 days of postnatal life. There were no significant changes in the glucose concentrations with age after birth (Table 1). In contrast, plasma $\alpha$-aminonitrogen concentrations increased significantly $(P<0 \cdot 002)$ between day 1 and 2 and then remained stable throughout the remaining 10-day period (Table 1). Plasma adrenaline concentrations were near or below the limit of detection of the assay on all days studied, whereas plasma noradrenaline concentrations were greatest on day 1 and decreased progressively $(P<0 \cdot 014)$ over the 10 days of the study (Table 1). Basal plasma insulin concentrations showed no significant change with postnatal age, whereas total proinsulin concentrations increased significantly between days 1 and 5 and then remained stable (Table 1). There was no relationship between birth weight and the basal concentration of either insulin $(r=0 \cdot 376, n=7$, $P>0.05)$ or total proinsulin $(r=0.301, n=7, P>0.05)$ on day 1 or subsequently $(P>0 \cdot 05$, all cases). 

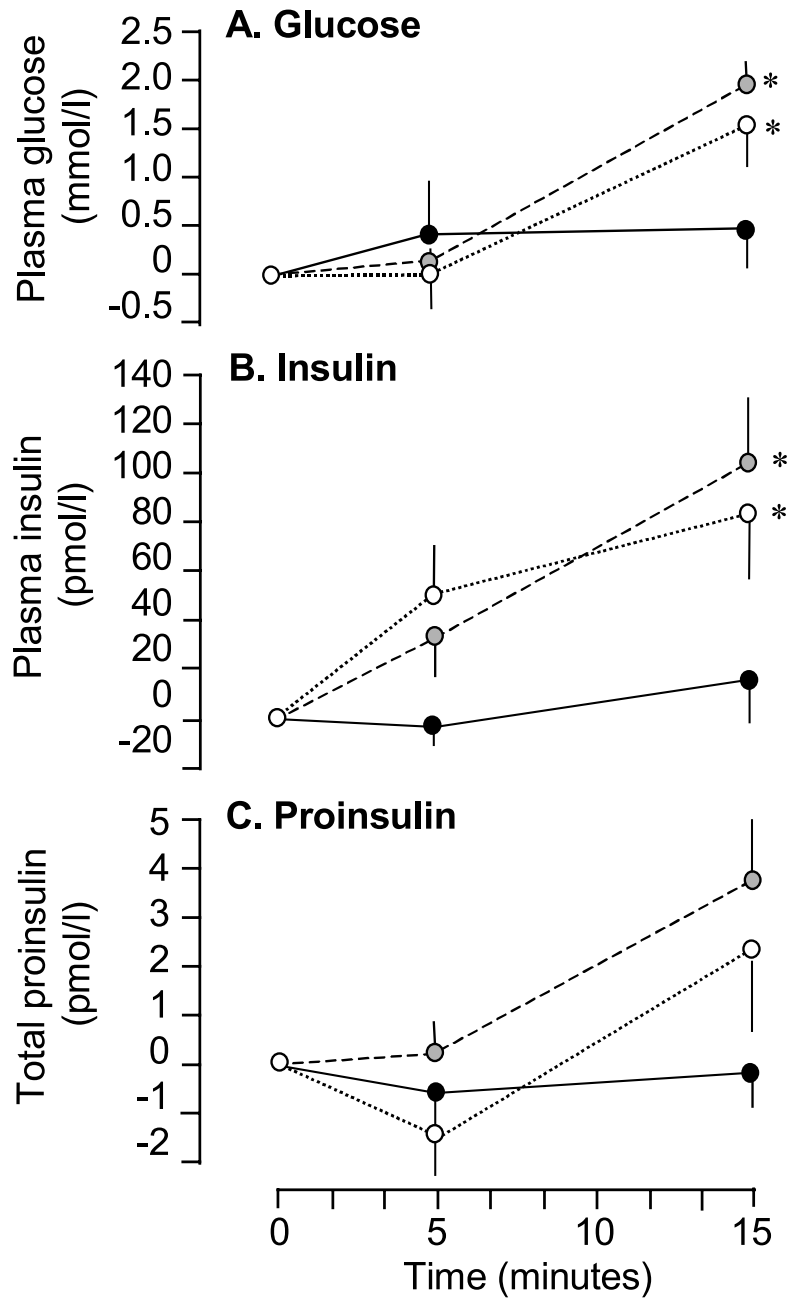

Figure 1 Mean ( \pm S.E.) increments in the plasma concentration of (A) glucose, (B) insulin and (C) total proinsulin after the onset of suckling at 0 min in seven pony foals on day $1(-)$, day 5 (C) and day $9(O)$ of postnatal life. *Significant increment from 0 min value (one-way ANOVA with repeated measures, $P<0 \cdot 05)$.

\section{Pancreatic $\beta$ cell responses to endogenous stimuli}

Suckling caused a gradual increase in the plasma glucose concentration on days 5 and 9 , but not on day 1 (Fig. 1A). Mean plasma glucose concentrations were significantly greater than the basal values $15 \mathrm{~min}$ after the onset of suckling on days 5 and 9 , but remained unchanged from baseline throughout the sampling period on day 1 (Fig. 1A). Plasma insulin concentrations increased in parallel with the glucose concentrations and were significantly greater than basal values 15 min after the onset of suckling on days 5 and 9, but not day 1 (Fig. 1B). The increments in plasma glucose and insulin evoked by suckling were similar on days 5 and 9 (Fig. 1A, B). There was no significant change in plasma proinsulin

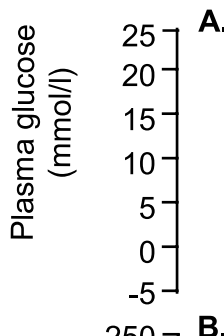

A. Glucose
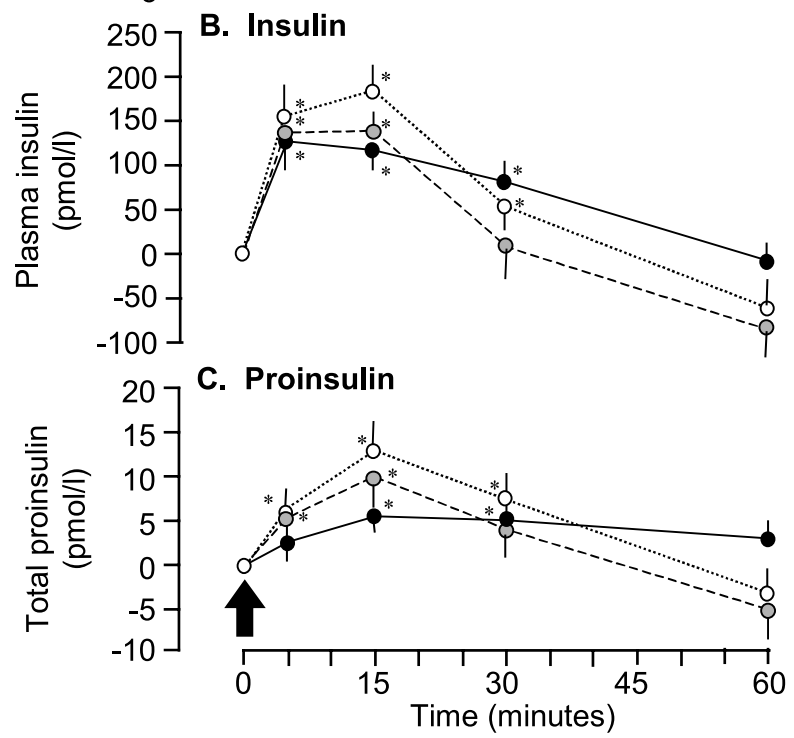

Figure 2 Mean $( \pm$ S.E.) increments in the plasma concentration (A) glucose, (B) insulin and (C) total proinsulin in response to intravenous glucose $(0.5 \mathrm{~g} / \mathrm{kg}$ in a $40 \%$ solution) given at time 0 in seven normal pony foals on day $1(\mathbf{O})$, day $5(\mathrm{C})$ and day $9(\bigcirc)$ of postnatal life. * Significant increment from 0 min value (one-way ANOVA with repeated measures, $P<0 \cdot 05$ ). Arrow indicates glucose administration.

concentrations during the 15 min period after the onset of suckling in any of the three age groups (Fig. 1C). Plasma concentrations of adrenaline and noradrenaline were not significantly different from the basal values $5 \mathrm{~min}$ after the onset of suckling (data not shown).

\section{Pancreatic $\beta$ cell responses to exogenous stimuli}

Glucose administration Administration of glucose caused a significant increment in the plasma glucose concentration, which was maximal at $5 \mathrm{~min}$ (Fig. 2A) and of similar magnitude in the three age groups (Table 2). Glucose concentrations decreased rapidly thereafter and were not significantly different from baseline values by 30 min after administration on days 5 and 9. On day 1, glucose concentrations remained increased at $30 \mathrm{~min}$, but had returned to basal values by $60 \mathrm{~min}$ after administration (Fig. 2A). The glucose AUC was, therefore, significantly greater on day 1 than on days 5 and 9 (Table 2). Glucose administration also evoked a rapid release of insulin at all three ages, with peak insulin concentrations at 5-15 min 
Table 2 Mean $( \pm$ S.E.) values of the maximum increment $(\Delta)$ and AUC for plasma glucose, $\alpha$-aminonitrogen, insulin and proinsulin in response to the exogenous administration of glucose or arginine in seven newborn pony foals with respect to postnatal age

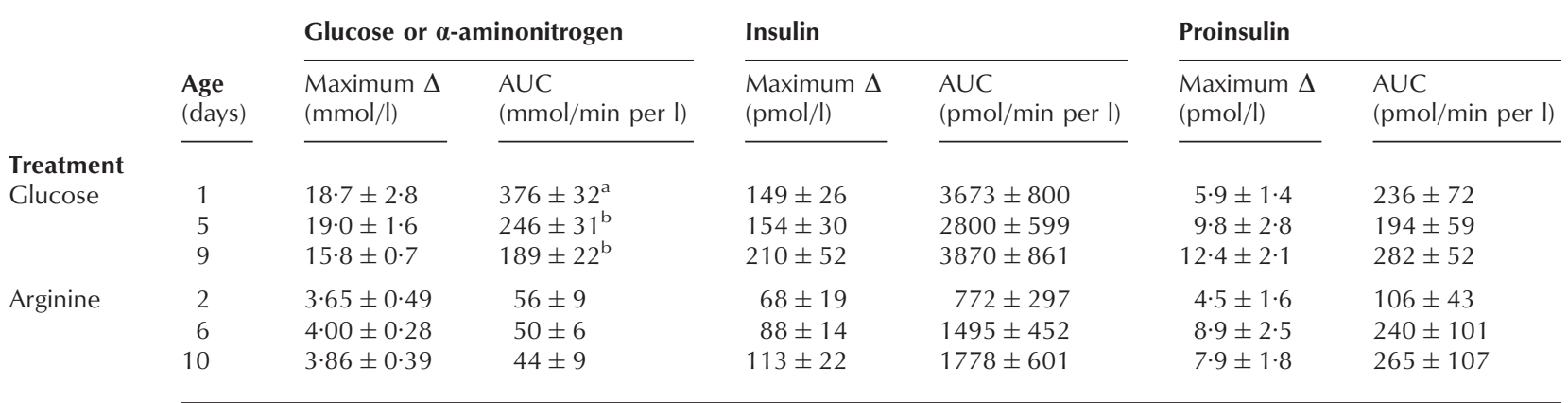

Within a treatment, values in a column with different superscript letters are significantly different from each other (one-way ANOVA with repeated measures, $P<0 \cdot 05$ ).

(Fig. 1B). The mean maximum increment in plasma insulin and the insulin AUC did not differ significantly with postnatal age (Table 2). The ratio of the insulin AUC to glucose AUC increased progressively with postnatal age and was significantly greater on day $9(21 \cdot 8 \pm 4 \cdot 6, n=7)$ than on day $1(9 \cdot 7 \pm 1 \cdot 5, n=7 ; P<0 \cdot 033)$. The glucoseinduced increment in plasma insulin was accompanied by a significant increase in the plasma proinsulin concentration at all three ages (Fig. 2C). Proinsulin concentrations peaked $15 \mathrm{~min}$ after the administration of glucose and declined slowly thereafter (Fig. 2C). The mean maximum increment in plasma proinsulin in response to glucose tended to increase with postnatal age, but this trend was not statistically significant $(P=0 \cdot 059$; Table 2$)$. The proinsulin AUC did not differ significantly with postnatal age (Table 2). The insulin AUC and proinsulin AUC were significantly correlated on day 1 , but not on days 5 and 9 (day 1: $r=0.934, n=7, P<0 \cdot 002$; day $5: r=0 \cdot 610, n=7$, $P>0.05$; day 9: $r=0 \cdot 421, n=7, P>0 \cdot 05)$.

Arginine administration Administration of arginine increased plasma $\alpha$-aminonitrogen concentrations to a similar extent in the three age groups (Fig. 3A). The mean maximum increase in plasma $\alpha$-aminonitrogen and the $\alpha$-aminonitrogen AUC in response to arginine were similar on days 2, 6 and 10 (Table 2). Arginine administration evoked a rapid release of insulin, with peak insulin concentrations at 5-15 min (Fig. 3B). The mean maximum increment in plasma insulin and the insulin AUC in response to arginine tended to increase with postnatal age, but these trends were not statistically significant $(P>0 \cdot 05$; Table 2). The maximum increment in plasma insulin and the insulin AUC were smaller in response to arginine than to glucose at each time period $(P<0.02$ in all cases; Table 2). There was also a gradual increase in the plasma proinsulin concentration in response to arginine at all three ages (Fig. 3C), which was similar in magnitude and time course to the proinsulin response to exogenous glucose at each time period (Fig. 2C). The mean maximum increment in plasma proinsulin and the proinsulin AUC in response to arginine tended to increase with postnatal age, but these trends were not statistically significant (Table 2). The proinsulin AUC was positively correlated to the

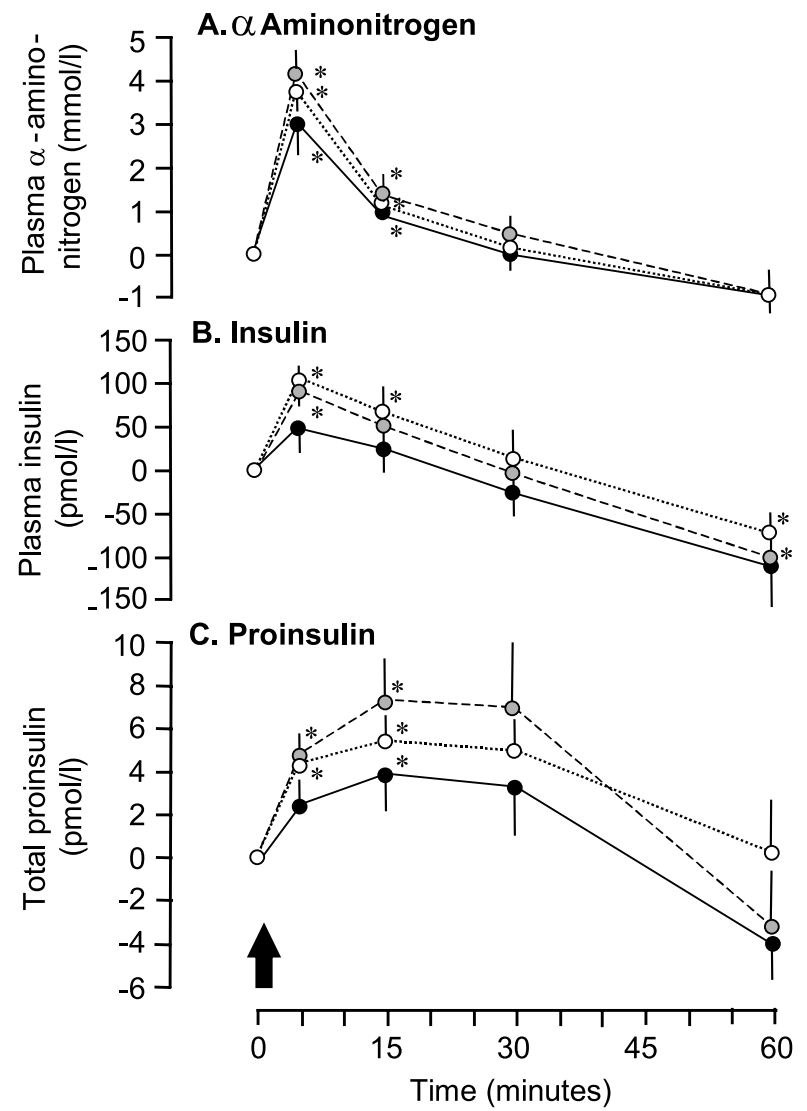

Figure 3 Mean ( \pm S.E.) increments in the plasma concentration of (A) $\alpha$-aminonitrogen, (B) insulin and (C) total proinsulin in response to intravenous arginine $(100 \mathrm{mg} / \mathrm{kg})$ given at $0 \mathrm{~min}$ in seven pony foals on day $2(\bullet)$, day $6(\mathrm{C})$ and day $10(\mathrm{O})$ of postnatal life. *Significant increment from 0 min value (one-way ANOVA with repeated measures, $P<0 \cdot 05)$. Arrow indicates time of arginine administration. 


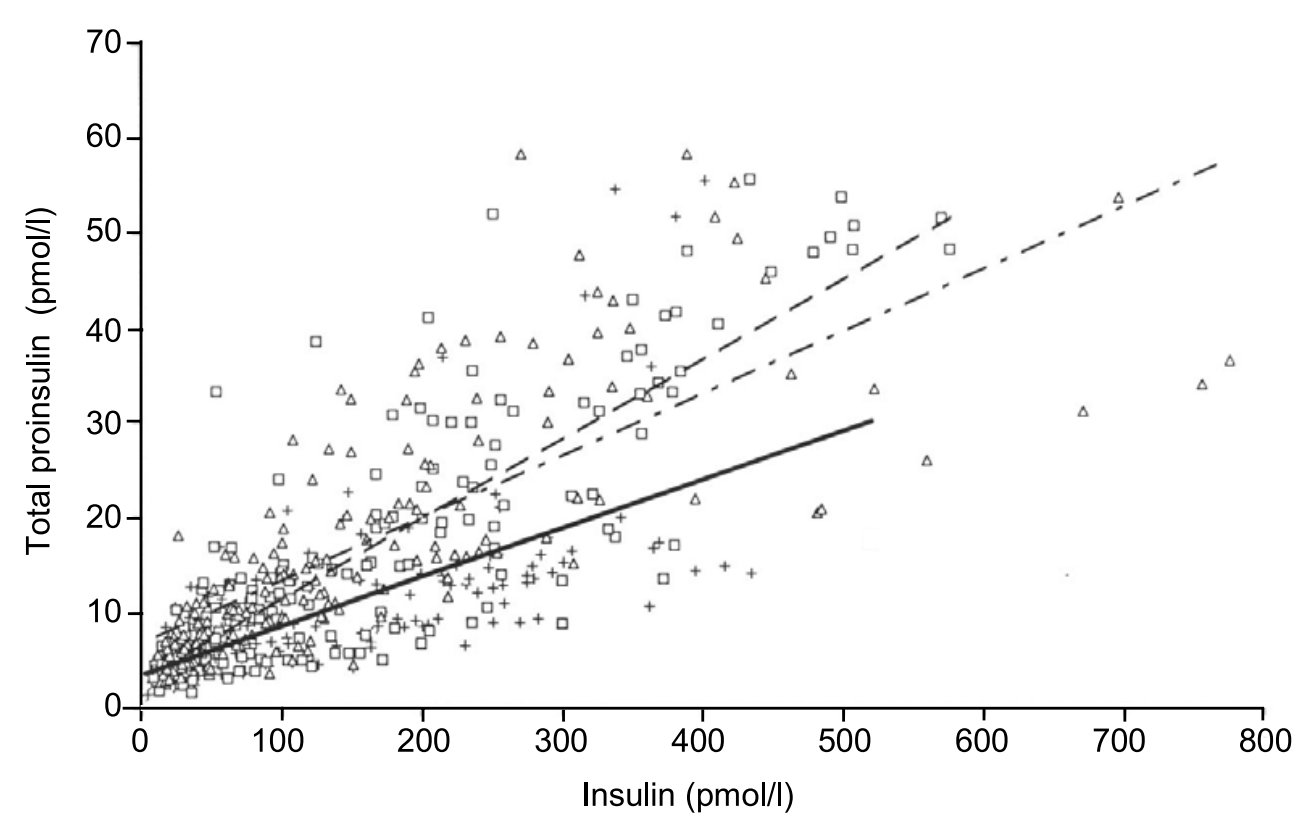

Figure 4 Relationship between the plasma insulin and total proinsulin concentrations in seven normal pony foals at three time periods after birth [period 1: days $1-2(+), y=0 \cdot 051 x+3 \cdot 479$; period 2: days 5-6 ( $\square), y=0 \cdot 0843 x+2 \cdot 9222$; period 3: days 9-10 $(\triangle), y=0 \cdot 0657 x+6 \cdot 722)$. Linear regression analysis showed that the gradients of the trendlines were significantly different for each time period: period 1 compared with period 2, $P<0.001$; period 1 compared with period 3, $P=0.016$; period 2 compared with period 3 , $P=0 \cdot 001$. Trendlines: - , period $1 ;-\cdot-$, period $2 ;-\cdot-\cdot$, period 3 .

AUC insulin at all three ages (day 2: $r=0 \cdot 766, n=7$, $P<0 \cdot 04$; day 6: $r=0 \cdot 827, n=7, P<0 \cdot 02$; day 10: $r=0 \cdot 771$, $n=7, P<0 \cdot 04)$. Mean glucose concentrations decreased progressively throughout the $60 \mathrm{~min}$ after the administration of arginine. The mean decrement in plasma glucose was significant at 30 and $60 \mathrm{~min}$ and was similar in magnitude at all three ages (data not shown).

Administration of saline on days 2, 6 and 10 had no significant effect on the plasma $\alpha$-aminonitrogen or insulin concentrations: mean values did not change significantly from basal values during the $60 \mathrm{~min}$ sampling period (data not shown). In contrast, plasma glucose concentrations were significantly lower than baseline by $60 \mathrm{~min}$ after saline administration on days 2 and 6, but not 10 (day 2: $-2.07 \pm 0.61 \mathrm{mmol} / 1, n=7, P<0.01$; day $6:-0.85 \pm$ $0.27 \mathrm{mmol} / 1, \quad n=7, \quad P<0.05 ; \quad$ day $10: \quad-0.64 \pm$ $0.40 \mathrm{mmol} / 1, n=7, P>0 \cdot 05)$. Proinsulin concentrations decreased progressively throughout the $60 \mathrm{~min}$ sampling period on all three days, but resulted in a significant decrement in concentration at 60 min only on days 6 and $10 \quad(-6.4 \pm 2.4 \mathrm{pmol} / \mathrm{l}$ and $-6.5 \pm 2.6 \mathrm{pmol} / 1$, respectively; $n=7, P<0 \cdot 05$ in both cases).

\section{Relationship between plasma insulin and proinsulin concentrations}

When all the data for each time period were combined irrespective of treatment, there was a significant linear relationship between the insulin and proinsulin concentrations at each of the three time periods after birth (Fig. 4). The gradient of this relationship was significantly shallower in period 1 than subsequently (Fig. 4).

\section{Discussion}

The results of this study demonstrate that there are changes in the mechanisms of secretion and action of insulin in the foal during the first 10 days of postnatal life. Both insulin and total proinsulin concentrations increased in response to the exogenous administration of glucose and arginine, whereas only the insulin concentration increased significantly when glucose concentrations were increased endogenously by suckling. Basal concentrations of total proinsulin, but not of insulin, also increased over the 10-day period of the study. Furthermore, the gradient of the linear relationship observed between the plasma insulin and proinsulin concentrations was shallower on days 1 and 2 post partum than subsequently. These ontogenic changes in the proinsulin concentrations and in the insulin/proinsulin relationship were accompanied by a decrease in the clearance of the exogenously administered glucose.

Insulin concentrations increased in the newborn foal in response to both exogenous and endogenous increases in the circulating glucose concentration. The time course and 
magnitude of these responses did not change significantly during the first 10 days of postnatal life and there was no evidence for a neural component to the suckling-induced increase in insulin in the foal, unlike the lamb and rabbit (Bassett \& Fletcher 1982). In the current study, the maximum increment in plasma insulin in response to exogenously administered glucose in suckled foals on day 1 was similar to that observed previously in pony foals at 7 days of age and was greater than that seen in utero during late gestation or in unsuckled foals $2-3 \mathrm{~h}$ after birth (Fowden et al. 1982, 1984). These observations suggest that, in foals, the major change in pancreatic $\beta$ cell sensitivity to glucose occurs with the onset of enteral feeding in the immediate neonatal period. However, the insulin response to glucose at 10 days of age was smaller than that seen in adult horses given a similar intravenous dose of glucose (Garcia \& Beech 1986, Giraudet et al. 1994). In the foals, the time course and magnitude of the insulin response to arginine also showed no change with postnatal age but, unlike the response to glucose, the insulin response to arginine did not change between late gestation and the neonatal period (Fowden et al. 1980, 1984). The neonatal insulin response to arginine was also consistently smaller than that to glucose throughout the 10-day period of the study. Although this may have been in part attributable to the decrease in plasma glucose, overall the current observations indicate that, in common with other species (Hermans et al. 1987, Gresores et al. 1997), arginine and glucose act through different mechanisms to stimulate the release of insulin from equine $\beta$ cells. The results also suggest that these two mechanisms are affected differentially by the nutritional adaptations at birth.

The maximum increment in plasma glucose and the insulin response to exogenous glucose were not significantly different on days 1, 5 and 9, but glucose clearance, measured as glucose AUC, was significantly slower on day 1 than subsequently. Hence, foals on day 1 may be insulin resistant and less responsive to the hypoglycaemic action of insulin. High concentrations of hyperglycaemic hormones may be responsible for this insulin antagonism. Noradrenaline concentrations were greater on day 1 than subsequently, and previous studies have shown that cortisol and glucagon concentrations are increased in foals during the first 24 h after birth (Silver et al. 1984, Fowden et al. 1999). Increased gluconeogenesis may also contribute to the reduced rate of glucose clearance on day 1 as the calorific intake in colostrum is inadequate to meet the energy requirements of the foal in the immediate neonatal period (Ousey et al. 1997). Indeed, there were no changes in the plasma glucose concentration after suckling on day 1 .

In adult humans, proinsulin concentrations are normally low and increase only in insulin-resistant conditions when the increased demand for insulin leads to the release of immature proinsulin-rich granules from the $\beta$ cells (Williams et al. 1991). High proinsulin concentrations are, therefore, a useful index of $\beta$ cell dysfunction and can be used to predict the development of adult-onset metabolic and cardiovascular diseases, such as type 2 (non-insulindependent) diabetes and coronary heart disease (Zethelius et al. 2002, 2003). In the foals, proinsulin was detected in plasma at all ages studied, although the concentrations were only $5-10 \%$ of those of insulin. Basal proinsulin concentrations in the foals on day 1 were similar to those seen in newborn human infants and increased over the next 10 days to reach values seen in normal adult humans during resting conditions (Godfrey et al. 1996, Tura et al. 2003). In newborn human infants, proinsulin concentrations are inversely correlated to birth weight (Godfrey et al. 1996), but no relationships were observed between basal plasma proinsulin and bodyweight of the foals in the current study, either on day 1 or subsequently.

Proinsulin secretion occurred in the foal in response to exogenous administration of glucose and arginine, but not when the increment in glucose was smaller and slower after suckling. Similar proinsulin responses to glucose and arginine have been observed in normal human volunteers (Stumvoll et al. 2001, Tura et al. 2003). In the foals, the proinsulin responses were smaller and prolonged compared with the corresponding insulin responses throughout the 10-day period of study. These observations are consistent with a relatively small store of proinsulin in the secretory granules and with the lower rate of proinsulin than insulin clearance seen in normal human individuals (Zilker et al. 1988, Sobey et al. 1989). Proinsulin may, therefore, accumulate in the circulation of the foal as the glucoregulatory demand on the $\beta$ cells increases with the onset of intermittent provision of nutrient after birth. This could also explain, in part, the increased gradient of the relationship between proinsulin and insulin concentrations seen after the first few days of postnatal life.

In summary, the results demonstrate that equine $\beta$ cells are responsive to both glucose and arginine during the immediate postnatal period. These secretagogues appeared to act through different mechanisms, and led to the release of insulin and proinsulin. Proinsulin and insulin concentrations were directly related, during both basal and stimulated conditions, although the gradient of this relationship was shallower on days 1 and 2 post partum than subsequently. As the secretion of proinsulin in response to glucose and arginine did not change with age of the foals, the increase in proinsulin concentrations over the first 10 days of postnatal life is more likely to reflect the slow clearance rate of proinsulin than a change in the proinsulin content of the secretory granules in the pancreatic $\beta$ cells.

\section{Acknowledgements}

We would like to thank Ian Halsall, Department of Clinical Biochemistry, University of Cambridge, for his assistance with the biochemical analyses. We are also 
grateful to Dr Fred Heath, Department of Clinical Veterinary Medicine, University of Cambridge, for his assistance with the statistical analyses.

\section{Funding}

We would like to thank the Horserace Betting Levy Board for their financial support. Conflicts of interest: None.

\section{References}

Aldoretta PW, Carver TD \& Hay WW Jr 1998 Maturation of glucose-stimulated insulin secretion in fetal sheep. Biology of the Neonate 73 375-386.

Andersen L, Dinesen B, Jørgensen P, Poulson F \& Røder M 1993 Enzyme immunoassay for intact insulin in serum or plasma. Clinical Chemistry $39578-582$.

Bassett JM \& Fletcher JM 1982 Hormonal regulation of fetal metabolism and growth: the roles of the pancreatic and adrenal hormones. In Biochemical Development of the Fetus and Neonate, ch 11, pp 393-423. Ed. Jones CT. Amsterdam: Elsevier.

Fowden AL 1985 Pancreatic endocrine function and carbohydrate metabolism in the fetus. In Perinatal Endocrinology, pp 71-90. Eds EB Albrecht \& G Pepe. Ithaca, New York: Perinataology Press.

Fowden AL 1995 Endocrine regulation of fetal growth. Reproduction Ferility and Development 7 351-363.

Fowden AL \& Hill DJ 2001 Intra-uterine programming of the endocrine pancreas. British Medical Bulletin 60 123-142.

Fowden AL, Barnes RJ, Comline RS \& Silver M 1980 Pancreatic $\beta$ cell function in the fetal foal and mare. Journal of Endocrinology 87 293-301.

Fowden AL, Ellis L \& Rossdale PD 1982 Pancreatic $\beta$ cell function in the neonatal foal. Journal of Reproduction and Fertility Supplement 32 529-535.

Fowden AL, Silver M, Ellis L, Ousey JC \& Rossdale PD 1984 Insulin secretion in the foal during the perinatal period. Equine Veterinary Journal 16 286-291.

Fowden AL, Li J \& Forhead AJ 1998 Glucocorticoids and the preparation for life after birth: are there long-term consequences of the life insurance? Proceedings of the Nutritional Society 57 113-122.

Fowden AL, Forhead AJ, Bloomfield MR, Taylor PM \& Silver M 1999 Pancreatic $\alpha$ cell function in the fetal foal during late gestation. Experimental Physiology 84 697-705.

Fowden AL, Ousey JC \& Forhead AJ 2001 Comparative aspects of prepartum maturation; provision of nutrients. Pferdheilkunde 17 653-658.

Garcia MC \& Beech J 1986 Equine intravenous glucose tolerance test: glucose and insulin responses of healthy horses fed grain or hay and of horses with pituitary adenoma. American Journal of Veterinary Research 47 570-572.

Giraudet A, Hinchcliff KW, Kohn CW \& McKeever KH 1994 Early insulin response to an intravenous glucose tolerance test in horses. American Journal of Veterinary Research 55 379-381.

Godfrey KM, Hales CN, Osmond C, Barker DJ \& Taylor KP 1996 Relationship of cord plasma concentrations of proinsulin, 32-33 split proinsulin and C-peptide to placental weight and the baby's size and proportions at birth. Early Human Development 46 129-140.

Gresores A, Anderson S, Hood D, Zerbe G \& Hay WW 1997 Separate and joint effects of arginine and glucose on ovine fetal insulin secretion. American Journal of Physiology 272 E68-E73.

Hemmiläi I, Dakubu S, Mukkala V, Siitari H \& Lovgren T 1984 Europium as a label in time-resolved immunofluorometric assays. Analytical Biochemistry 137 335-343.
Hermans MP, Schmeer W \& Henquin JC 1987 The permissive effect of glucose, tolbutamide and high $\mathrm{K}+$ on arginine stimulation of insulin release in isolated mouse islets. Diabetologia 30 659-665.

Madigan JE 1991 Hypoglycaemia. In Manual of Equine Neonatal Medicine, edn 2, ch 44, pp 201-202. Woodland, CA, USA: Live Oak Publishing.

Orsi L, Lambert AE, Kanazawa Y, Amhersdt M, Rouiller C \& Renold AE 1971 Morphological and biochemical studies of $\beta$ cells of foetal rat endocrine pancreas in organ culture: evidence of (Pro) insulin biosynthesis. Journal of Cell Biology 50 565-582.

Ousey JC, Pradi S, Zimmer J, Holdstock NB \& Rossdale PD 1997 Effects of various feeding regimes on the energy balance of equine neonates. American Journal of Veterinary Research 58 1243-1251.

Phillips AF, Dubin JW \& Raye JR 1981 Maturation of early phase insulin release in the neonatal lamb. Biology of the Neonate 39 225-231.

Prenton MA \& London DR 1967 The continuous in vivo monitoring of plasma amino nitrogen. Technicon Monographs 2 70-75.

Rossdale PD, Ousey JC, Silver M \& Fowden A 1984 Studies on equine prematurity 6: guidelines for assessment of foal maturity. Equine Veterinary Journal 16 300-302.

Silver M, Ousey JC, Dudan FE, Fowden AL, Knox J, Cash RSG \& Rossdale PD 1984 Studies on equine prematurity 2: post natal adrenocortical activity in relation to plasma adrenocorticotrophic hormone and catecholamine levels in term and premature foals. Equine Veterinary Journal 16 278-285.

Silver M, Fowden AL, Ousey JC, Knox J, Franco R \& Rossdale PD 1987 Sympathoadrenal response to hypoglycaemia in the foal. Journal of Reproduction and Fertility Supplement 35 607-614.

Sobey WJ, Beer SF, Carrington CA, Clark PM, Frank BH, Gray IP, Luzio SD, Owens BR, Schneider AE \& Siddle K 1989 Sensitive and specific two-site immunoradiometric assays for human insulin, proinsulin, 65-66 and 32-33 split proinsulin. Biochemical Journal 260 535-541.

Spurlock SL \& Furr M 1990 Disorders of glucose metabolism. In Equine Clinical Neonatology, pp 684-686. Philadelphia, USA: Lea \& Febinger.

Stomvoll M, Fritsche A, Stefan N, Hardt E \& Haring H 2001 Evidence against a rate-limiting role of proinsulin processing for maximal insulin secretion in subjects with impaired glucose tolerance and $\beta$ cell dysfunction. Journal of Clinical Endocrinology and Metabolism 86 1235-1239.

Trahair JF \& Sangild PT 1997 Systemic and luminal influences on the perinatal development of the gut. Equine Veterinary Medicine Supplement 24 40-50.

Tura A, Pacini G, Kautzky-Willer A, Ludvik B, Prager R \& Thomaseth K 2003 Basal and dynamic proinsulin-insulin relationships to assess $\beta$ cell function during OGTT in metabolic disorders. American Journal of Physiology 285 E155-E162.

Williams DRR, Byrne C, Clark PMS, Cox L, Day NE, Rayman G, Wang T \& Hales CN 1991 Raised proinsulin concentration as early indicator of beta cell function. British Medical Journal 303 95-96.

Zethelius B, Byberg L, Hales CN, Lithell H \& Berne C 2002 Proinsulin as an independent predictor of coronary heart disease: report from a 27-year follow-up study. Circulation 105 2153-2158.

Zethelius B, Byberg L, Hales CN, Lithell H \& Berne C 2003 Proinsulin and acute insulin response independently predict type 2 diabetes mellitus in men - report from 27 years of follow-up study. Diabetologia 46 20-26.

Zilker TR, Gray IP, Hales CN, Wahl K, Ermler R, Lebender A, Heinzel G \& Bottermann P 1988 Pharmokinetics of biosynthetic human proinsulin following intravenous and subcutaneous administration in metabolically healthy volunteers. Hormone and Metabolism Research Supplement 18 37-43.

Received in final form 27 February 2004 Accepted 27 February 2004 